University of Nebraska - Lincoln

DigitalCommons@University of Nebraska - Lincoln

Publications from USDA-ARS / UNL Faculty

U.S. Department of Agriculture: Agricultural

Research Service, Lincoln, Nebraska

$11-7-2007$

\title{
The Mycotoxin Threat to Food Safety
}

Ervin Balazs

Department of Applied Genomics, Agricultural Research Institute, Hungary

James S. Schepers

University of Nebraska-Lincoln, james.schepers@gmail.com

Follow this and additional works at: https://digitalcommons.unl.edu/usdaarsfacpub

Part of the Agricultural Science Commons

Balazs, Ervin and Schepers, James S., "The Mycotoxin Threat to Food Safety" (2007). Publications from USDA-ARS / UNL Faculty. 189.

https://digitalcommons.unl.edu/usdaarsfacpub/189

This Article is brought to you for free and open access by the U.S. Department of Agriculture: Agricultural Research Service, Lincoln, Nebraska at DigitalCommons@University of Nebraska - Lincoln. It has been accepted for inclusion in Publications from USDA-ARS / UNL Faculty by an authorized administrator of DigitalCommons@University of Nebraska - Lincoln. 


\section{The Mycotoxin Threat to Food Safety}

This workshop entitled "Mycotoxins from the Field to the Table" held in Omaha, Nebraska, USA from 29 November to 1 December, 2006 evolved from the OECD (Organisation for Economic Co-operation and Development) Co-operative Research Programme on "Biological Resource Management" that was initiated in 1979. It currently focuses on three specific areas, namely the natural resources challenge, sustainability in practice, and the food chain. This workshop was organized under the sustainability and food chain themes.

The Cooperative Research Program's two major activities are promotion of expert exchanges by supporting postdoctoral fellowship awards up to 26 weeks in an OECD host laboratory and sponsoring or co-sponsoring workshops under the themes priority areas. Currently participating countries in the program are: Australia, Austria, Belgium, Canada, Czech Republic, Denmark, Finland, France, Germany, Greece, Hungary, Ireland, Italy, Japan, Korea, The Netherlands, New Zealand, Norway, Poland, Portugal, Slovak Republic, Spain, Sweden, Switzerland, United Kingdom and the United States of America. The program usually sponsors 6 to 8 expert workshops per year. All information related to this program can be located at the internet website of OECD (www.oecd.org/arg/prog/). Any further information can be obtained from the OECD, Mr. Carl-Christian Schmidt, Head of the Co-operative Research Programme, Trade and Agriculture Directorate, 2, rue André Pascal, 75775 Paris Cedex 16, France (email: Carl-Christian. Schmidt@oecd.org).

The workshop on "Mycotoxins from the Field to the Table" was motivated by the fact that mycotoxins have become a key problem of our food chain, starting in the field and ending on the table. Over the last few decades, it became obvious that commonly occurring fungi growing in foods and feeds may produce toxins known as mycotoxins. Mycotoxins, the secondary metabolites of fungi, have structures which may be cytotoxic, carcinogenic immunosuppressant or estrogenic, causing severe disorders and diseases in humans, pets and livestock. Some of the most frequently occurring toxins are produced by Fusarium species on different crops, especially wheat, barley and maize. Some of these can end up in the daily human diet in foods and animal feeds such as cereals, and cereal products. In temperate climates, the most important toxins are deoxynivalenol (DON), zearalenone (F-2), diacetoxyscirpenol (DAS), T-2 toxin and the fumonisins. When these compounds are produced in cereals during the growing season or after harvest these toxins may be introduced into the food and feed chains and cause various disorders such as feed refusal, vomiting, nervous system disturbances, diarrhea, irregular or absent estrous cycles, decreased milk production, leucoencephalomalacia in the case of horses, and pulmonary edema in pigs. Fumonisnins are thought to be a major cause of esophageal cancer in humans in areas of South Africa. Some members of Aspergillus and Penicillium genera, found in barley, green coffee and grapes, produce Ochratoxin A, which is teratogenic and a potential carcinogen. Aspergillus flavus and $A$. parasiticus produce aflatoxins which may contaminate maize and peanuts.

Food safety is a major concern around the world and the driving force of all aspects of mycotoxin research, starting with the prevention of diseases in fields, followed by the protection of stored food and feed against post-harvest contamination, and ending with mycotoxin detection systems in the animal feed and human food. Due to recent developments in molecular biology, highly sophisticated and sensitive techniques have been discovered and described. These tools are now available for monitoring of mycotoxins. Among those are enzyme linked immunoassays using polyclonal or monoclonal antibodies. These techniques are commonly incorporated into routine laboratory detection systems. Today national and international legislation regulates the mycotoxin contamination levels allowed in different feeds and foods, and have been extended to the beer and wine industries in that mycotoxins have been traced to these products. The workshop in Omaha covers nearly all aspects of mycotoxin concerns and represents state of the art mycotoxin research, starting with an overview of the different toxins and the biodiversity of mycotoxin producing fungi. It also covers new monitoring systems and the development of diagnostic tools, with a special section on managing the risk of mold and mycotoxin contamination in the supply chain. The workshop's invited speakers that gathered in Omaha are not only among the most respected 
experts in this complex field, but they represent many of the laboratories of the world most actively working in these areas of research. Lectures presented and published in the proceedings as a Special Issue of "The International Journal of Food Microbiology" represent the conclusions and opinions of the authors, and do not necessarily reflect the views of their organizations, the workshop organizers, OECD and its member countries, nor the authors' countries' concerns.
Theme 3 Coordinator Ervin Balázs

Department of Applied Genomics, Agricultural Research Institute, H-2462 Martonvásár, Brunszvik u 2, Hungary.

James S. Schepers

Soil and Water Conservation Research, USDA-ARS, NPA, 113 Keim Hall, University of Nebraska, Lincoln, NE 68583-0915, 